\section{Polyethylenglykol-modifizierte Enzyme}

\author{
K. J. Lackner ${ }^{1}$ und D. Peetz ${ }^{2}$ \\ ${ }^{1}$ Institut für Klinische Chemie und Laboratoriumsmedizin, \\ Universitätsmedizin Mainz, Mainz, Deutschland \\ ${ }^{2}$ Institut für Labormedizin, Helios Klinikum Berlin-Buch, \\ Berlin, Deutschland
}

Englischer Begriff polyethylenglycol modified enzymes

Definition Mit Polyethylenglykol konjugierte Enzyme.

Beschreibung Die Modifikation von Proteinen mit Polyethylenglykol wird dazu genutzt, ihre Eigenschaften (z. B. Halbwertszeit im Blut bei Therapeutika) zu verändern.
In der Labordiagnostik werden PEG-modifizierte Cholesterinesterase und Cholesterinoxidase zur homogenen Bestimmung von HDL-Cholesterin eingesetzt. Dabei hat sich PEG mit einer mittleren Molmasse von $6 \mathrm{kDa}$ als am besten geeignet erwiesen. In Verbindung mit $\alpha$-Cyclodextrin im Reaktionsansatz reagieren sie mit hoher Spezifität nur mit Cholesterin in HDL-Partikeln.

\section{Literatur}

Langlois MR, Blaton VH (2006) Historical milestones in measurement of HDL-cholesterol: impact on clinical and laboratory practice. Clin Chim Acta 369:168-178

Sugiuchi H, Uji Y, Okabe H et al (1995) Direct measurement of highdensity lipoprotein cholesterol in serum with polyethylene glycolmodified enzymes and sulfated alpha-cyclodextrin. Clin Chem 41:717-723 